\title{
Deksametason Untuk Mengurangi Respon Inflamasi Pada Bedah Jantung Berdasarkan Kadar C-Reactive Protein Plasma
}

\section{Dexamethasone to Reduce Inflammatory Response in Heart Surgery Based on Plasma C-Reactive Protein Level}

Widya Istanto Nurcahyo ${ }^{\bowtie}$, Hanugra Julius Sayoga

Bagian Anestesiologi dan Terapi Intensif, Fakultas Kedokteran, Universitas Diponegoro/ RSUP Dr. Kariadi, Semarang, Indonesia

${ }^{\square}$ Korespondensi: widya_istanto2@yahoo.com

\begin{abstract}
Background: Open heart surgery is one type of surgery with major trauma, in daily practice using a cardiopulmonary bypass $C P B$ ) machine. The use of a CPB machine causes massive inflammatory response that is characterized by increase in $C$-Reactive Protein (CRP). One way to suppress CRP production is by using dexamethasone. Dexamethasone dose with premedication technique that is often used is $1 \mathrm{mg} / \mathrm{kg}$ and 2 $m g / \mathrm{kg}$.

Purpose: To compare dexamethasone effect at dose of $1 \mathrm{mg} / \mathrm{kg}$ and $2 \mathrm{mg} / \mathrm{kg}$ as a premedication on CRP level post CPB in cardiac surgery.

Methods: This study was a randomized clinical trial which included 18 heart surgery patients with general anesthesia and using a CPB machine. The sample was divided into 2 group, each group received dexamethasone at a dose of $1 \mathrm{mg} / \mathrm{kg}$ and a dose of 2 $\mathrm{mg} / \mathrm{kg}$ respectively as a premedication technique. The level of CRP between two doses then compared preoperative and postoperatively.

Results: In this study, there is no significant increase on CRP level in both groups (dexamethasone $1 \mathrm{mg} / \mathrm{kg}[p=0,813]$ and dexamethasone $2 \mathrm{mg} / \mathrm{kg}[\mathrm{p=0,115]}$ ). Comparison of postoperative CRP levels in the dexamethasone group of $1 \mathrm{mg} / \mathrm{kg}$ with $2 \mathrm{mg} / \mathrm{kg}$ was found to be insignificant ( $p=0.596)$.

Conclusion: There is no difference between $1 \mathrm{mg} / \mathrm{kg}$ and $2 \mathrm{mg} / \mathrm{kg}$ dexamethasone premedication in reducing infalammatory response in heart surgery on CPB.
\end{abstract}

Keywords: CPB; CRP; dexamethasone; heart surgery; inflammation; premedication

\begin{abstract}
ABSTRAK
Latar belakang: Bedah jantung terbuka merupakan salah satu jenis operasi dengan trauma yang cukup besar, dalam pelaksanaannya menggunakan mesin
\end{abstract}


Cardiopulmonary Bypass (CPB). Penggunaan mesin CPB menyebabkan respon inflamasi yang luas dan ditandai dengan peningkatan $C$-Reactive Protein (CRP). Salah satu cara untuk menekan produksi CRP ini dengan menggunakan deksametason. Dosis deksametason dengan teknik pemberian premedikasi yang sering digunakan yaitu 1 $\mathrm{mg} / \mathrm{kgbb}$ dan $2 \mathrm{mg} / \mathrm{kgbb}$.

Tujuan: Membandingkan efek deksametason dengan dosis $1 \mathrm{mg} / \mathrm{kgbb}$ dan dosis 2 $\mathrm{mg} / \mathrm{kgbb}$ sebagai premedikasi terhadap kadar CRP pasca CPB pada operasi jantung.

Metode: Penelitian ini merupakan uji klinik acak yang mengikutsertakan 18 pasien bedah jantung dengan anestesi umum dan menggunakan mesin CPB. Sampel dibagi 2 kelompok, yaitu deksametason dosis $1 \mathrm{mg} / \mathrm{kgbb}$ dan dosis $2 \mathrm{mg} / \mathrm{kgbb}$ sebagai premedikasi. Membandingkan jumlah CRP pada masing-masing dosis deksametason saat praoperasi dan pascaoperasi.

Hasil: Pada penelitian ini, tidak ditemukan peningkatan yang bermakna dari kadar CRP pada kedua kelompok (deksametason $1 \mathrm{mg} / \mathrm{kg}$ [p=0,813] dan deksametason $2 \mathrm{mg} / \mathrm{kg}$ $[\mathrm{p}=0,115])$. Perbandingan kadar CRP pascaoperasi antara kelompok deksametason 1 $\mathrm{mg} / \mathrm{kg}$ dengan kelompok deksametason $2 \mathrm{mg} / \mathrm{kg}$ didapatkan hasil yang tidak bermakna $(\mathrm{p}=0,596)$,

Simpulan: Tidak didapatkan perbedaan antara pemberian premedikasi deksametason 1 $\mathrm{mg} / \mathrm{kg}$ dengan deksametason $2 \mathrm{mg} / \mathrm{kg}$ dalam menurunkan respon inflamasi pada operasi jantung dengan CPB.

Kata kunci: bedah jantung; CPB; CRP; deksametason; inflamasi; premedikasi

\section{PENDAHULUAN}

Bedah jantung terbuka merupakan salah satu jenis operasi dengan trauma yang cukup besar, yang dalam pelaksanaannya diperlukan suatu periode yang disebut periode sirkulasi luar tubuh (Ekstra Corporal Circulation) atau disebut juga Cardiopulmonary Bypass (CPB). Dalam melakukan proses sirkulasi luar tubuh digunakan suatu mesin yaitu mesin pintas jantung paru. ${ }^{1}$

Salah satu efek merugikan dari pemakaian mesin pintas jantung paru adalah terjadi kontak antara darah dengan berbagai benda asing atau biomaterial dari sirkuit mesin jantungparu (misal: kanul-kanul, oksigenator, tubing dan lain-lain). ${ }^{2}$ Keadaan ini mengakibatkan teraktivasinya komponen seluler darah yaitu: eritrosit, endotel vaskular, leukosit, neutrofil, monosit, platelet maupun sistem koagulasi dan komponen non seluler (humoral) darah yaitu mediator inflamasi dan sistem komplemen yang kesemuanya dapat memicu timbulnya systemic inflamatory response syndrome (SIRS), yang ditandai dengan meningkatnya kadar $C$-Reactive Protein $(\mathrm{CRP})>4 \mathrm{mg} / \mathrm{L}$ setelah operasi. ${ }^{3,4}$

Respon inflamasi sistemik setelah operasi jantung bersifat multifaktorial. Seperti yang telah dijelaskan sebelumnya, istilah SIRS tidak terlalu banyak dapat membantu dalam mengklarifikasi patofisiologi inflamasi pada operasi jantung. Tampaknya tidak terdapat banyak pertentangan akan pernyataan bahwa semua proses inflamasi ini dapat terjadi dan mungkin bertanggung jawab 
untuk menyebabkan komplikasi pada pasien yang menjalani bedah jantung. ${ }^{5}$

Trauma jaringan, endotoksemia, dan kontak antara darah dengan permukaan benda asing pada sirkuit CPB diperkirakan dapat memulai respon inflamasi sistemik setelah tindakan operasi jantung. ${ }^{6}$

Mediator-mediator proinflamasi dan anti inflamasi terbukti berperan penting dalam kejadian SIRS, mediatormediator tersebut diantaranya adalah: Tumor Necrosis Factor $\alpha$ (TNF- $\alpha$ ), Interleukin I $\beta$ (IL-I $\beta$ ), Interleukin -6 (IL-6), Platelet Activating Factor (PAF), sedangkan mediator anti inflamasi diantaranya adalah Interleukin-10 (IL10). ${ }^{7}$

Diantara mediator-mediator proinflamasi, TNF- $\alpha$ muncul paling awal pada fase akut dan mengaktifkan berbagai sel diantaranya: neutrofil, sel endotel dan fibroblas. Pada bedah jantung terbuka peningkatan kadar serum TNF- $\alpha$ dalam serum terjadi pada saat proses sirkulasi luar tubuh berjalan dan adanya trauma operasi. ${ }^{8}$

Selain kontaknya darah dengan lapisan dalam dari sirkuit mesin jantung-paru, penyebab lain terjadinya SIRS pada bedah jantung terbuka adalah: Ischemicreperfusion injury, endotoksin, dan trauma operasi. Walaupun pengaruhnya relatif kecil terhadap timbulnya SIRS dibanding dengan kontaknya darah dengan lapisan dalam sirkuit mesin jantung-paru, ischemic reperfusion injury, endotoksin dan trauma operasi, keadaan-keadaan seperti hipotermi, anemi relatif, pemberian heparin selama sirkulasi luar tubuh berlangsung dan pemberian protamin setelah sirkulasi luar tubuh diakhiri dapat menyebabkan timbulnya SIRS, oleh karena itu SIRS tetap timbul walaupun sirkulasi luar tubuh telah dihentikan. ${ }^{9}$

Hal ini berakibat terjadinya pengaktifan suatu proses inflamasi antara lain pelepasan dari sitokin. Pelepasan sitokin ini akan berakibat bertambahnya kadar CRP yang berada di sel hepatosit di hati, dan menjadi tahapan awal terjadinya proses inflamasi yang bertanggung jawab terhadap kerusakan jaringan dan organ tubuh. ${ }^{10}$ Gejala ini biasanya dikenal sebagai SIRS. Peningkatan kadar CRP dalam sirkulasi merupakan salah satu tanda adanya SIRS. ${ }^{11,12}$

Selain disebabkan oleh penggunaan mesin $C P B$, kejadian SIRS pada operasi bedah jantung terbuka juga dapat disebabkan oleh ischemia reperfusion injury. ${ }^{13}$ Ischemia reperfusion injury berhubungan dengan respon inflamasi akut yang di mediasi oleh sitokin, kemokin, dan adhesi molekul-molekul seperti neutrofil, monosit dan sel inflamasi lainnya yang dapat mengakibatkan iskemik otot jantung. ${ }^{14,15}$

Kortikosteroid banyak digunakan dalam pengobatan inflamasi karena kemampuannya dalam berinteraksi dengan respon imun. ${ }^{16}$ Penggunaan kortikosteroid dosis rendah pada sepsis tahap awal masih menjadi perdebatan. ${ }^{17}$ Telah diterangkan bahwa penggunaan kortikosteroid dosis tinggi jangka pendek tidak menunjukkan efek yang bermakna. Namun banyak penelitian baru yang menggunakan dosis lebih rendah jangka panjang dan memperlihatkan efek yang bermakna. ${ }^{18}$ Efek positif ini juga dapat memulihkan syok, menurunkan disfungsi sistem organ dan menurunkan tingkat mortalitas. ${ }^{19}$ 
Penggunaan kortikosteroid merupakan strategi untuk mengoreksi terjadinya SIRS pada pasien jantung yang menjalani $\mathrm{CPB}^{20}$ Penggunaan kortikosteroid pada preoperatif memodulasi plasma dan respon sel inflamatori. ${ }^{21}$ Penggunaan kortikosteroid sebagai premedikasi baik dengan dosis $1 \mathrm{mg} / \mathrm{kgbb}$ ataupun 2 $\mathrm{mg} / \mathrm{kgbb}$ telah dilakukan di berbagai operasi jantung yang menggunakan mesin CPB. ${ }^{22}$ Dalam studi ini peneliti ingin membandingkan kadar CRP pada masing-masing perlakuan, untuk melihat efektivitas dan efisiensi dosis pemberian kortikosteroid sebagai obat antiinflamasi.

Beberapa penelitian sebelumnya telah menjelaskan operasi jantung baik menggunakan CPB ataupun tidak, terbukti dapat mengakibatkan peningkatan kadar CRP. Penelitian lain juga menjelaskan bahwa pemberian deksametason baik sebagai premedikasi maupun intra operatif terbukti memiliki pengaruh terhadap penurunan kejadian inflamasi pada pasien yang menjalani operasi jantung, baik dilihat berdasarkan klnis, kadar interleukin (IL)-6, maupun lama rawat. ${ }^{23,24,25}$

Berdasarkan uraian latar belakang di atas, maka peneliti ingin membandingkan pemberian deksametason dengan dosis $1 \mathrm{mg} / \mathrm{kgbb}$ dan dosis $2 \mathrm{mg} / \mathrm{kgbb}$ sebagai premedikasi terhadap kadar CRP setelah CPB pada operasi jantung. Dari hasil penelitian ini, diharapkan dapat menjadi dasar acuan untuk pemilihan dosis deksametason yang paling tepat sebagai premedikasi dalam operasi jantung dengan CPB.

\section{METODE}

Penelitian ini merupakan penelitian eksperimental dengan pendekatan uji klinik dan dirancang sebagai uji klinis dengan rancangan klinikal trial dengan metode randomized control trial yang menilai efektivitas deksametason untuk mengurangi inflamasi berdasarkan kadar CRP plasma pada bedah jantung. Populasi yang diikutsertakan dalam penelitian ini adalah semua pasien yang akan menjalani operasi bedah jantung yang menggunakan mesin CPB di Instalasi Bedah Sentral (IBS) Rumah Sakit Umum Pusat (RSUP) Dr. Kariadi Semarang dalam kurun waktu bulan Maret sampai dengan April 2019.

Pada penelitian ini terdapat dua kelompok yaitu premedikasi deksametason dengan dosis $1 \mathrm{mg} / \mathrm{KgBB}$ dan premedikasi deksametason dengan dosis $2 \mathrm{mg} / \mathrm{KgBB}$. Sampel yang ditentukan sebanyak sembilan subjek untuk masing-masing kelompok. Kriteria inklusi pada penelitian ini adalah (1) usia 18-65 tahun; (2) menjalani operasi bedah jantung yang menggunakan mesin CPB; (3) hasil pemeriksaan darah rutin dalam batas normal; dan (4) fungsi ginjal dan hati dalam batas normal. Kriteria eksklusi pada penelitian ini adalah (1) waktu CPB lebih dari 90 menit; (2) dalam pengobatan statin dan aspirin; dan (3) perempuan dalam masa menstruasi.

Penelitian dilaksanakan di Intensive Cardiac Care Unit (ICCU) RSUP Dr. Kariadi Semarang setelah mendapatkan persetujuann komite etik. Sampel darah diambil sebelum operasi dan 6 jam setelah operasi untuk diperiksa kadar CRP dan leukositnya. Hasil pemeriksaan laboratorium diolah dan ditampilkan dalam bentuk tabel untuk 
selanjutnya diolah dan dianalisis secara statistik menggunakan SPSS 23.0

\section{HASIL}

Sebanyak 18 pasien bedah jantung terbuka masuk dalam kriteria inklusi dalam sampel penelitian. Masingmasing kelompok didapatkan 9 sampel penelitian. Selama penelitian tidak ada sampel penelitian yang drop out. Keseluruhan sampel penelitian didapatkan 18 pasien, terdiri atas 12 laki-laki $(66,7 \%)$ dan 6 perempuan $(33.3 \%)$.

Tabel 1. Data demografi

\begin{tabular}{llll}
\hline \multirow{2}{*}{ Variabel } & \multicolumn{2}{c}{ Teknik } & \multirow{2}{*}{ P } \\
\cline { 2 - 3 } & $1 \mathrm{mg} / \mathrm{kg}$ & $2 \mathrm{mg} / \mathrm{kg}$ & \\
\hline Jenis kelamin & $5(55,6 \%)$ & $7(77,8 \%)$ & $0,620 ¥$ \\
Laki-laki & $4(44,4 \%)$ & $2(22,2 \%)$ & \\
Perempuan & $42,78 \pm 12,88$ & $48,11 \pm 13,48$ & $0,403 \S$ \\
Umur & & \\
\hline
\end{tabular}

Keterangan: ${ }^{¥}$ Chi square; ${ }^{\S}$ Independent t

Pada tabel 1 dapat dilihat bahwa tidak didapatkan perbedaan bermakna $(\mathrm{p}>$
0,05) dari data demografi pada kedua kelompok penelitian.

Tabel 2. Perbedaan CRP praoperasi dan pascaoperasi

\begin{tabular}{|c|c|c|c|}
\hline \multirow{2}{*}{ CRP } & \multicolumn{2}{|c|}{ Teknik } & \multirow{2}{*}{$\mathrm{P}$} \\
\hline & $1 \mathrm{mg} / \mathrm{kg}$ & $2 \mathrm{mg} / \mathrm{kg}$ & \\
\hline Pre & $0,46 \pm 0,47$ & $0,29 \pm 0,19$ & $0,895^{\dagger}$ \\
\hline Post & $0,40 \pm 0,37$ & $0,50 \pm 0,44$ & $0,596^{\dagger}$ \\
\hline $\mathrm{p}$ (berpasangan) & $0,813^{\dagger}$ & $0,115^{\pi}$ & \\
\hline
\end{tabular}

Tidak terdapat perbedaan bermakna pada kadar CRP pra dan pascaoperasi baik pada kelompok deksametason 1 $\mathrm{mg} / \mathrm{kgbb}$ maupun $2 \mathrm{mg} / \mathrm{kgbb}(\mathrm{p}=0,813$ dan $\mathrm{p}=0,115)$. Perbandingan kadar
CRP pascaoperasi pada kelompok deksametason $1 \mathrm{mg} / \mathrm{kgbb}$ dengan 2 $\mathrm{mg} / \mathrm{kgbb}$ didapatkan perbedaan yang tidak bermakna $(\mathrm{p}=0,596)$

Tabel 3. Pengaruh pemberian deksametason terhadap GDS

\begin{tabular}{llll}
\hline \multirow{2}{*}{ GDS } & \multicolumn{2}{l}{ Teknik } & P \\
\cline { 2 - 3 } & $1 \mathrm{mg} / \mathrm{kg}$ & $116,11 \pm 18,77$ & $0,808^{\S}$ \\
\hline Pre & $113,22 \pm 29,69$ & $150,44 \pm 28,75$ & $0,109^{\S}$ \\
Post & $175,22 \pm 32,97$ & $<0,001^{\mathbb{I} *}$ & \\
\hline p (berpasangan) & $<0,001^{\mathbb{I} *}$ & Keterangan: & Bermakna $(\mathrm{p}<0,05) ;{ }^{\mathbb{T}}$ Paired $\mathrm{t} ;{ }^{\S}$ Independent $\mathrm{t}$
\end{tabular}

Terdapat perbedaan bermakna dalam pada kedua kelompok $(\mathrm{p}<0,001)$. perubahan GDS pra dan pascaoperasi 
Tabel 4. Pengaruh pemberian deksametason terhadap leukosit

\begin{tabular}{|c|c|c|c|}
\hline \multirow{2}{*}{ Leukosit } & \multicolumn{2}{|l|}{ Teknik } & \multirow{2}{*}{$\mathrm{P}$} \\
\hline & $1 \mathrm{mg} / \mathrm{kg}$ & $2 \mathrm{mg} / \mathrm{kg}$ & \\
\hline Pre & $8,67 \pm 1,61$ & $7,80 \pm 1,44$ & $0,246^{\S}$ \\
\hline Post & $13,64 \pm 3,07$ & $12,72 \pm 2,15$ & $0,471^{\S}$ \\
\hline p (berpasangan) & $0,002^{\mathbb{I} *}$ & $<0,001^{\mathbb{I} *}$ & \\
\hline
\end{tabular}

Terdapat perbedaan bermakna dalam perubahan leukosit pra dan pascaoperasi pada kedua kelompok $(\mathrm{p}=0,002$ dan $\mathrm{p}<0,001)$.

Tabel 5. Pengaruh pemberian deksametason terhadap tanda vital pada praoperasi dan 6 jam pascaoperasi

\begin{tabular}{|c|c|c|c|c|c|c|}
\hline \multirow{3}{*}{ Variabel } & \multicolumn{6}{|c|}{ Teknik } \\
\hline & \multicolumn{3}{|c|}{$1 \mathrm{mg} / \mathrm{kg}$} & \multicolumn{3}{|c|}{$2 \mathrm{mg} / \mathrm{kg}$} \\
\hline & pre & $6 \mathrm{jam}$ & $\mathrm{P}$ & pre & $6 \mathrm{jam}$ & $\mathrm{p}$ \\
\hline Suhu & $35,79 \pm 0.41$ & $36,18 \pm 0,60$ & $0,076^{\mathbb{I}}$ & $35(35-36,2)$ & $36(36-37)$ & $0,011^{\dagger *}$ \\
\hline Nadi & $85,78 \pm 5,70$ & $80,78 \pm 4,09$ & $0,046^{\mathrm{I} *}$ & $78,11 \pm 8,42$ & $77,00 \pm 4,30$ & $0,678^{\mathbb{I}}$ \\
\hline $\begin{array}{c}\text { Laju } \\
\text { napas }\end{array}$ & $14(13-16)$ & $14(13-15)$ & $0,527^{\dagger}$ & $14(14-15)$ & $13(13-15)$ & $0,157^{\dagger}$ \\
\hline
\end{tabular}

Keterangan: * Bermakna $(\mathrm{p}<0,05) ;{ }^{\mathbb{I l}}$ Paired $\mathrm{t} ;{ }^{\dagger}$ Wilcoxon

Pada tabel 5 untuk pemberian dosis deksametason $1 \mathrm{mg} / \mathrm{kgbb}$ pada praoperasi dibandingkan 6 jam pascaoperasi terjadi perubahan yang bermakna pada nadi $(\mathrm{p}=0,046)$, tetapi nilainya masih dalam batas normal. Sedangkan untuk pemberian dosis deksametason $2 \mathrm{mg} / \mathrm{kgbb}$ pada praoperasi dibandingkan 6 jam pascaoperasi terjadi perubahan yang bermakna pada suhu $(\mathrm{p}=0,011)$ tetapi nilainya masih dalam batas normal.

\section{PEMBAHASAN}

Pada penelitian ini untuk pemeriksaan suhu, laju pernafasan dan nadi yang merupakan indikator petanda terjadinya peningkatan reaksi inflamasi didapatkan hasil yang tidak bermakna. Hal ini disebabkan karena pasien masih dalam kontrol ventilator.

Pemberian deksametason $1 \mathrm{mg} / \mathrm{kgBB}$ dan $2 \mathrm{mg} / \mathrm{kgBB}$ memengaruhi kadar CRP pascaoperasi, tetapi pemberian deksametason $\quad 1 \quad \mathrm{mg} / \mathrm{kgBB}$ menyebabkan penurunan kadar CRP plasma tetapi perubahannya tidak bermakna.

Peningkatan kadar gula darah sewaktu pada pemberian deksametason dosis 1 $\mathrm{mg} / \mathrm{kgbb}$ dan $2 \mathrm{mg} / \mathrm{kgbb}$ bermakna pada masing-masing perlakuan. Peningkatan kadar GDS pada penelitian ini dikarenakan terjadinya peningkatan produksi glukoneogenesis di hepar yang disebabkan oleh kortikosteroid golongan glukokortikoid, yang pada penelitian ini menggunakan deksametason.

Hubungan pemberian deksametason 1 $\mathrm{mg} / \mathrm{kgbb}$ dan $2 \mathrm{mg} / \mathrm{kgbb}$ terhadap perubahan tanda vital pasien (nadi, suhu, laju pernafasan (RR) yang diukur sebelum operasi dan 6 jam sesudah operasi terdapat beberapa tanda vital yang berubah secara bermakna tetapi 
perubahan tersebut masih dalam batas nilai normal.

Perubahan kadar CRP yang didapatkan pada penelitian ini sesuai dengan efek deksametason yang dapat menekan respon imun humoral. Peningkatan secara bermakna juga terjadi pada kadar leukosit pra dan pascaoperasi pada pemberian deksametason $1 \mathrm{mg} / \mathrm{kgbb}$ dan $2 \mathrm{mg} / \mathrm{kgbb}$. Peningkatan leukosit ini dipicu oleh penggunaan mesin CPB yang bersifat immunoreactor dan menyebabkan neutrofilia. Pengaktifan leukosit ini akan berakibat bertambahnya jumlah sel leukosit yang berada di sirkulasi dan menjadi tahapan awal terjadinya proses inflamasi yang bertanggung jawab terhadap kerusakan jaringan dan organ tubuh. Gejala ini biasanya dikenal sebagai SIRS. ${ }^{6}$

Peningkatan jumlah leukosit dalam sirkulasi merupakan salah satu tanda adanya SIRS. Penggunaan kortikosteroid (dexamethason) merupakan strategi untuk mengkoreksi terjadinya SIRS pada pasien operasi jantung yang menjalani CPB. ${ }^{13}$

Penggunaan kortikosteroid pada preoperatif memodulasi plasma dan respon sel radang Penggunaan kortikosteroid sebagai premedikasi menjadi salah satu cara untuk menurunkan jumlah CRP selain dengan menggunakan teknik priming. ${ }^{13}$

Pada beberapa kasus, bentuk imatur atau abnormal dari sel darah putih dapat muncul dalam peredaran darah dan ikut terhitung dalam nilai hitung jenis. Bentuk imatur yang ada yaitu metamielosit, mielosit, promielosit, atau blas. Sebagai konfirmasi diperlukan pemeriksaan lanjutan berupa apusan darah tepi atau biopsi sumsum tulang.

\section{KESIMPULAN}

Tidak didapatkan perbedaan antara pemberian premedikasi deksametason $1 \mathrm{mg} / \mathrm{kg}$ dengan deksametason $2 \mathrm{mg} / \mathrm{kg}$ dalam menurunkan respon inflamasi pada operasi jantung dengan $\mathrm{CPB}$.

\section{DAFTAR PUSTAKA}

1. Cohn LH. "Fifty years of openheart

surgery". Circulation.2003;17: 2168-70.

2. Lim M. The history of extracorporeal oxygenators. Anaesthesia. 2006;1 0: 984-95

3. Buisson BC. The epidemiology of systemic inflammatory response. Intensive are Med. 2000;26(1):S64-74

4. Laffey JG, Boylan JF, Cheng DC. The systemic inflammatory response to cardiac surgery: implications for the anesthesiologist. Anesthesiology. 2002; 97(1):215-252

5. Lord, Janet M., Mark J. Midwinter, Yen-Fu Chen. "The Systemic Immune Response to Trauma: An Overview of Pathophysiology and Treatment." The Lancet 384.9952 (2014): 1455-465

6. Mangano D. Biventricular function after myocardial revascularization in humans: Deterioration and recovery patterns during the first 24 hours. Anesthesiology. 1985; 62(5): 571577

7. Hensley FA, Martin DE, Gravlen GP. A practical approach to cardiac anesthesia. 3rd ed. Philadelphia: Lippincott Williams \& Wilkins. 2003; 21:411-525 
8. Nathan,C. "Neutrophils and immunity: challenges and opportunities". Nature Reviews Immunology.2006; 6: 173-82

9. Wesraby S. Organ dysfunction after cardiopulmonary bypass: a systemic inflamatory reaction initiated by the extracorporeal circuit. Intensive Care Med. 1999;13:89-95

10. Shrivastava AK, Singh HV. Creactive protein, inflammation and coronary heart disease. The Egyptian Heart Journal 2015;67:89-97.

11. Djillali A, Sebille C, Charpentier PE, Bollaert B. Effect of treatment with low dose of hydrocortisone and fludrocortisone on mortality in patients with septic shock. JAMA. 2002; 288:862-871

12. Annane D, Bellissant E, Bollaert PE, Briegel J, Confalonieri M, De Gaudio R et al. Corticosteroids in the treatment of severe sepsis and septic shock in adults: a systematic review. JAMA. 2009; 301: 2362-2375

13. Goodman S, Charles LS. The international sepsis forum, $\mathrm{s}$ controversies in sepsis: corticosteroids should be used to treat Septic Shock. Crit care. 2002; 6(5): 381-383

14. Nicola R. Sproston, Jason J. Ashworth. Role of C-Reactive Protein at Sites of inflammation and infection. 13 April 2018

15. Semple SJ. C-reactive proteinbiological functions, cardiovascular disease and physical exercise. SAJSM. 2006;18(1):24-8

16. Ho KM, Tan JA. Benefits and risks of corticosteroid prophylaxis in adult cardiac surgery: a doseresponse meta-analysis.
Circulation.

2009;199:1853-66

17. Sobieski MAI, Graham JD, Pappas PS, Tatooles AJ, Slaughter MS. Reducing the Effects of the Systemic Inflammatory Response to Cardiopulmonary Bypass: Can Single Dose Steroids Blunt Systemic Inflammatory Response Syndrome? ASAIO Journal. April 2008;54(2):203.

18. Jansen NJ, Van OW, Gu YJ. Endotoxin release and tumor nekrosis factor formation during cardioplumonary bypass. Ann thorac Surg 1992; $54: 744-48$

19. Miller BE. The Inflamatory response to cardiopulmonary bypass. J Cardiothorac Vasc Anesthesia. 1997;11:355-66

20. Donihi AC, Raval D, Saul M, Korytkowski MT, DeVita MA (2006). "Prevalence and predictors of corticosteroid-related hyperglycemia in hospitalized patients". Endocr Pract. 12(4): 358-62

21. Kirklin JK, Westaby S, Blackstone EH, Kirklin JW, Chenoweth DE, Pacifico AD: Complement and the damaging effects of cardiopulmonary bypass. J Thorac Cardiovasc Surg. 1983; 86:845-57

22. Whitlock RP, Chan S, Devereaux PJ, Sun J, Rubens FD, Thorlund $\mathrm{K}$, dkk. Clinical benefit of steroid use in patients undergoing cardiopulmonary bypass: a metaanalysis of randomized trials. European Heart Journal. 20 Mei 2008;29(21):2592-600.

23. Aouifi A, Piriou V, Blanc $P$, Bouvier H, Bastien O, Chiari P, dkk. Effect of cardiopulmonary bypass on serum procalcitonin and C-reactive protein 
concentrations. British Journal of Anaesthesia.

Oktober 1999;83(4):602-7.

24. Dieleman JM, Nierich AP, Rosseel PM, Maaten JM van der, Hofland J, Diephuis JC, dkk. Intraoperative High-Dose Dexamethasone for Cardiac Surgery: A Randomized Controlled Trial. JAMA. 7 November 2012;308(17):1761-7.

25. Murphy GS, Sherwani SS, Szokol JW, Avram MJ, Greenberg SB, Patel KM, dkk. Small-Dose Dexamethasone Improves Quality of Recovery Scores After Elective Cardiac Surgery: A Randomized, Double-Blind, Placebo-Controlled Study. Journal of Cardiothoracic and Vascular Anesthesia. 1 Desember 2011;25(6):950-60. 